\title{
The research of anti corrosive properties of various compositions on samples of standard metals
}

\author{
Y.J. Aghazada, Vaqif M. Abbasov, Sanan E. Abdullayev, Elgun K. Hasanov, Sevinc S. Suleymanova \\ Azerbaijan National Academy of Sciences, Institute of Petrochemical Processes Named After Acad, Yu.G. Mamedaliyev, \\ AZ1025, Azerbaijan, Baku, Khojali ave. 30 \\ "Corresponding author: e-mail: yeqana.aqazade@mail.ru
}

\begin{abstract}
In this proceeding. the compositions of the T-30 turbine oil with liquid rubber. Co. $\mathrm{Ni}$. $\mathrm{Zn}$. $\mathrm{Mg}$ and $\mathrm{Ba}$ salts of the natural petroleum acids (NPA) boiling in the range $220-340^{\circ} \mathrm{C}$ and nitro compounds which are produced on the basis of $\mathrm{C}_{14} \mathrm{H}_{28} \alpha$-olefins have been investigated in different ratio and contents as metalworking fluids (MWF). The physical and chemical properties of the produced compositions have been studied. and the morphology of inhibited carbon steel surface was analyzed and characterized by using Fourier transform infrared (FTIR) and scanning electron microscopy (SEM) techniques. The effect of the temperature on the inhibition efficiency and thermodynamic parameters have also been reported. The thermal analyzer was used for the thermogravimetric analysis (TG/DTA) of the prepared MWF. The experiments have been operated with different concentrations of the inhibitor on the steel plates in condensation and environment phases in the experiment chamber.
\end{abstract}

Keywords: metalworking fluids and lubricants, corrosion, liquid rubber, natural petroleum acids.

\section{INTRODUCTION}

Corrosion is defined as the deterioration of a material due to reaction with its environment. Regardless of their operation conditions. metal constructions show the thermodynamically unstable state as they react with the aggressive part of the environment and corrode. This harmful attack can cause the defect in the mechanical. physical and chemical properties of metal ${ }^{1-3}$. Therefore. protection methods should be developed to reduce the damage effects of the metal. Inhibitors have very wide application in a variety of industrial applications such as cooling systems. refinery units. pipelines. chemicals. oil and gas production units. boilers and water processing. paints. pigments. lubricants. etc. ${ }^{4-8}$ Organic inhibitors are very effective way for the reducing of corrosion of metals and alloys due to generate a thin film that controls and prevents access to corrosive agents to the metal surface. The inhibitory effect of an organic inhibitor is reinforced by the presence of hetero adsorption active centers such as sulphur $(\mathrm{S})$. nitrogen $(\mathrm{N})$ and oxygen $(\mathrm{O})$ atoms in its molecule ${ }^{9-11}$. In addition to the molecular electronic structure with a number of these active centers. the molecular size. the mode of adsorption. the formation of metallic complexes. and the projected area of the inhibitor on the metallic surface also affect the efficiency of inhibition ${ }^{12-14}$.

In recent years. some experimental studies have been done to describe the corrosion and electrochemical behavior of stainless steel in concrete environment ${ }^{15-18}$. The widespread investigation of the inhibitors in the metalworking fluids is based on its economic efficiency and simple structure of application technology. The addition of a small amount of an inhibiting substance to the aggressive system is enough for protecting the metal without any changes to the current technical system ${ }^{19-21}$. The purpose of the work is to synthesize multifunctional nitrogen containing corrosion inhibitors with different molecular masses on the basis of local feedstocks with enough reserves and to prepare high - performance MWF by using them as additives.
In the given proceeding. the solution of the composition of inhibitor that is obtained by the complex of the $\mathrm{Co}, \mathrm{Ni}$, $\mathrm{Zn}, \mathrm{Mg}$ və $\mathrm{Ba}$ metal salts of the natural petroleum acids with nitro compounds and liquid rubber in T-30 oil has been applied as a corrosion protector. The compounds those have inhibitor properties in the prepared MWF mainly consist of 3 components: metal salts of natural petroleum acid. aliphatic based nitro compounds and liquid rubber.

\section{EXPERIMENTAL}

The metal (Co. Ni. Zn. Mg. Ba) salts of technical petroleum acids which are separated from Azerbaijan kerosene and diesel fractions and is soluble in organic solvents have been synthesized by the general methods. The NPA (It is obtained from the refinery of the Azerbaijan petroleum in the "Merichem" (USA) unit of the Baku Oil Refinery) which is used in the process has been obtained by the dearomatization of the diesel fraction with the boiling range of $220-340^{\circ} \mathrm{C}$. The dearomatization process has been operated with the extraction method. N-methyl pyrrolidone has been used as an extract. The physical and chemical properties of the fraction which is obtained from the extraction process were like this: $\varrho_{4}^{20}=0.8294 \mathrm{~g} / \mathrm{cm}^{3} ; \mathrm{n}_{d}^{20}=1.4677 ; \mathrm{M}_{\mathrm{B}}=$ 187 ; freezing point $=-51^{\circ} \mathrm{C}$; boiling point $=220-340^{\circ} \mathrm{C}$. kinematic viscosity at $20^{\circ} \mathrm{C} \sim 5.52 \mathrm{~mm}^{2} / \mathrm{sec}$. total sulfur content $\sim 0.03 \%$. the amount of aromatic hydrocarbons $\sim 1 \%$ (by mass).

The composition of the solution which contains synthesized the metal salts of the NPA and nitro compound with the polybutadiene based liquid rubber has been prepared and tested on steel plates. The liquid rubber which is used in the process has been synthesized on the basis of stereo regular structured 1.4 cis - polybutadiene (low molecular weight. $\mathrm{M}_{\mathrm{r}} \sim 1800-3000$ ). which has a wide range of industrial application (micro structure: 1.4 cis$-75 \sim 80 \%$; 1.4 trans-18 22\%; 1.2-units-2 7\%. number of units $\sim 80$ ). The cis- position of the methyl groups in liquid rubber facilitates the adsorption on the metal surface $^{22-23}$. Nitro compound is synthesized by using treat- 
ing $\mathrm{C}_{14} \mathrm{H}_{28}$ which is produced by the oligomerization of ethylene with nitro compound with nitric acid in optimum condition (sodium nitrite is used as an initiator). The amount of the active components was 1:1:1 (in grams). "T-30" turbine oil has been used as a solvent.

The physical and chemical properties of the composition of inhibitor have been investigated and its content has been proved by IR spectroscopy method ${ }^{24-25}$.

Name of the samples

I. T-30 oil + Co salt of the NPA + Nitro compound+liquid rubber;

II. T-30 oil $+\mathrm{Ni}$ salt of the NPA + Nitro compound+liquid rubber;

III. T-30 oil $+\mathrm{Zn}$ salt of the NPA + Nitro compound+liquid rubber;

IV. T-30 oil $+\mathrm{Mg}$ salt of the NPA + Nitro compound+liquid rubber;

V. T-30 oil + Ba salt of the NPA + Nitro compound+liquid rubber.

In order to determine the identity of the conservation liquid. 5 different points have been chosen on given sample and IR spectra have been evaluated ${ }^{26}$ (Fig. 1.1. - Fig. 1.6.). The following wavelength has been obtained by the spectral analysis of the conservation content of the inhibitor (Co salt of NPA + Nitro compound + liquid rubber) which shows the maximum efficiency:

The content of the composition has been tested by IRFurye LUMOS (BRUKER) microscope in the range of $600-4000 \mathrm{~cm}^{-1}$ wavelength. The deformation (1376-1457 $\mathrm{cm}^{-1}$ ) and valence $\left(2921-2950 \mathrm{~cm}^{-1}\right)$ oscillations of structure groups $\left(\mathrm{CH}_{3}\right.$ and $\left.\mathrm{CH}_{2}\right)$ which belong to NPA are observed in the spectrum of the approved sample. At the same time. the resonance signals for $\mathrm{C}-\mathrm{H}$ bond and valence oscillations for $\mathrm{C}-\mathrm{NO}_{2}$ group are seen at $723 \mathrm{~cm}^{-1}$ and $1558 \mathrm{~cm}^{-1}$ wavelength. respectively. The comparison of the IR spectrum of all 5 points on the sample shows that they are practically the same which

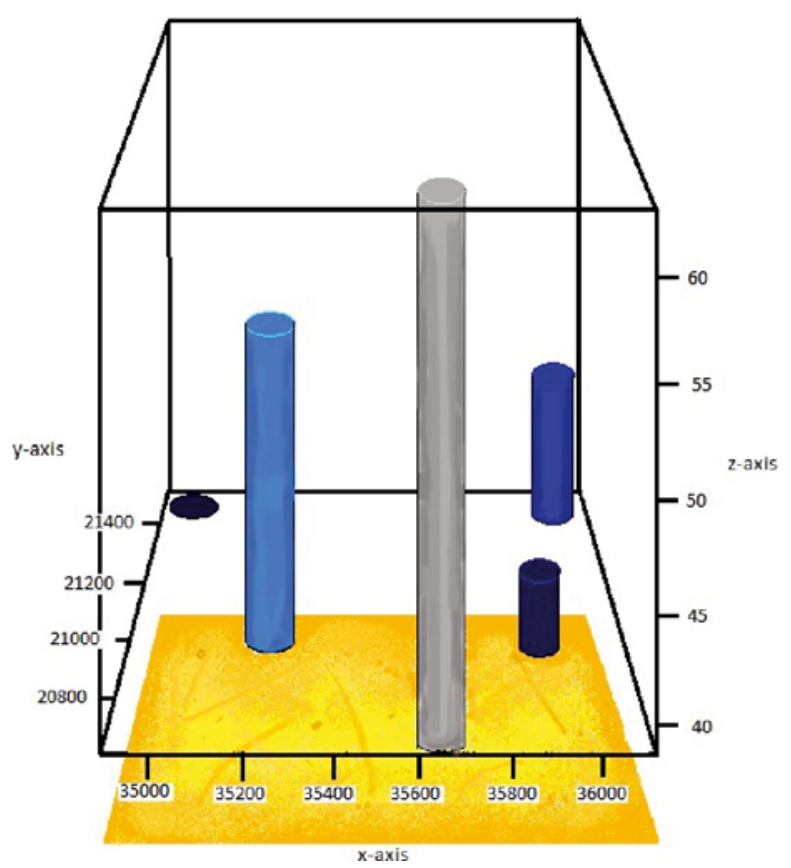

Figure 1.1. The microscopic view of 5 selected points in sample

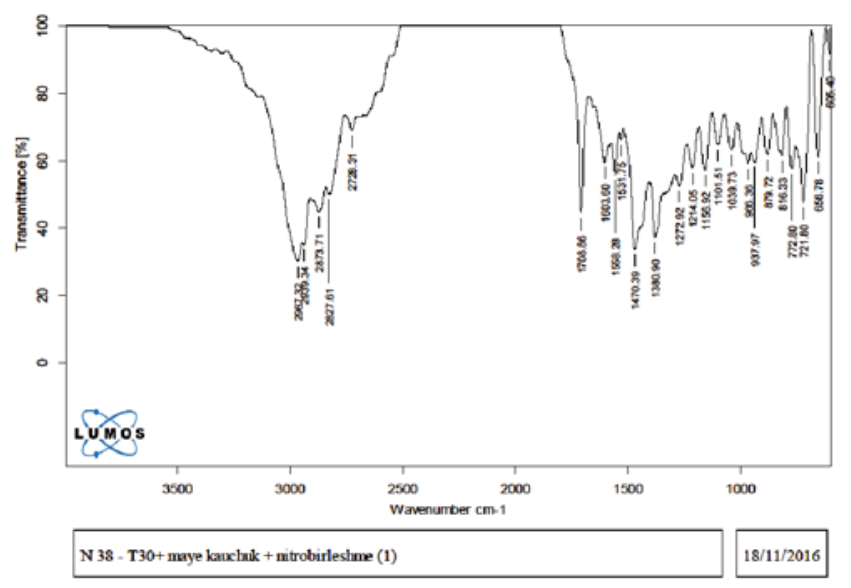

Figure 1.2. IR spectra of the $1^{\text {st }}$ point

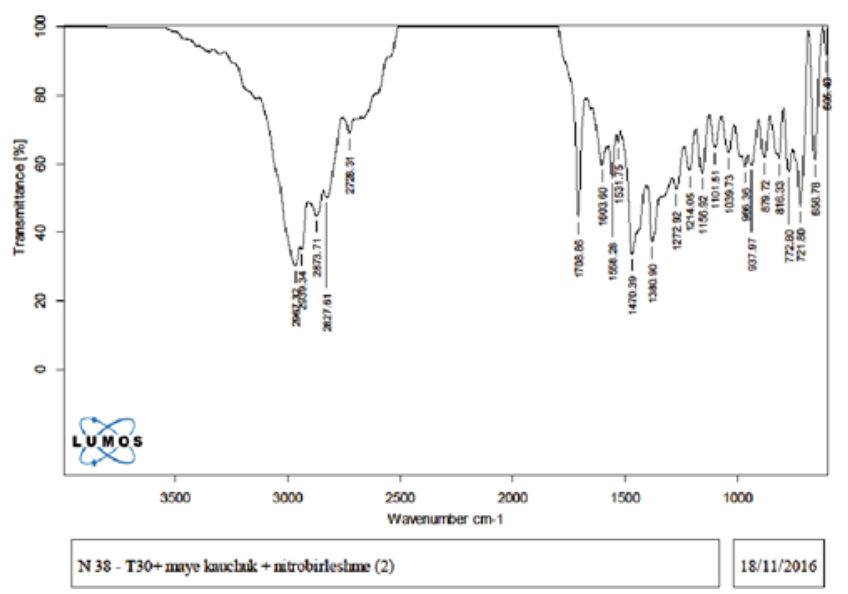

Figure 1.3. IR spectra of the $2^{\text {nd }}$ point

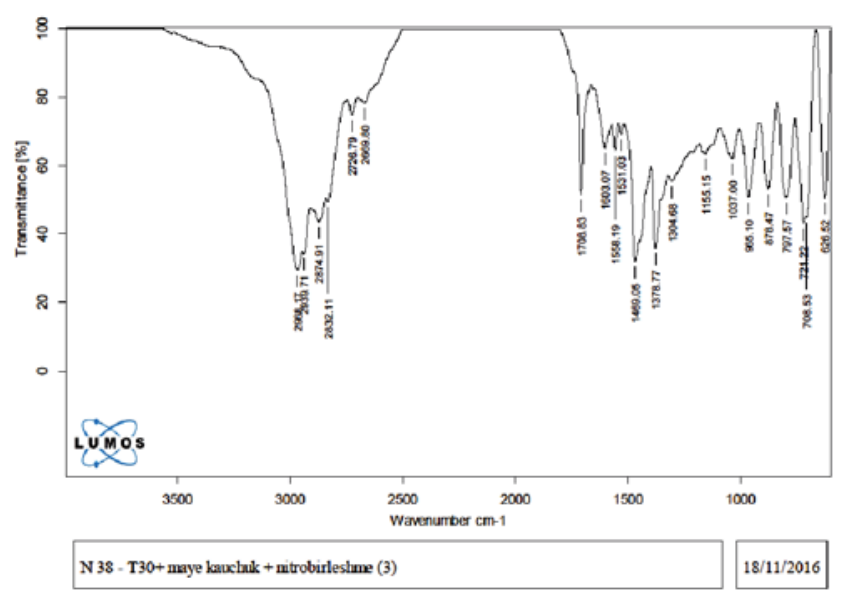

Figure 1.4. IR spectra of the $3^{\text {rd }}$ point

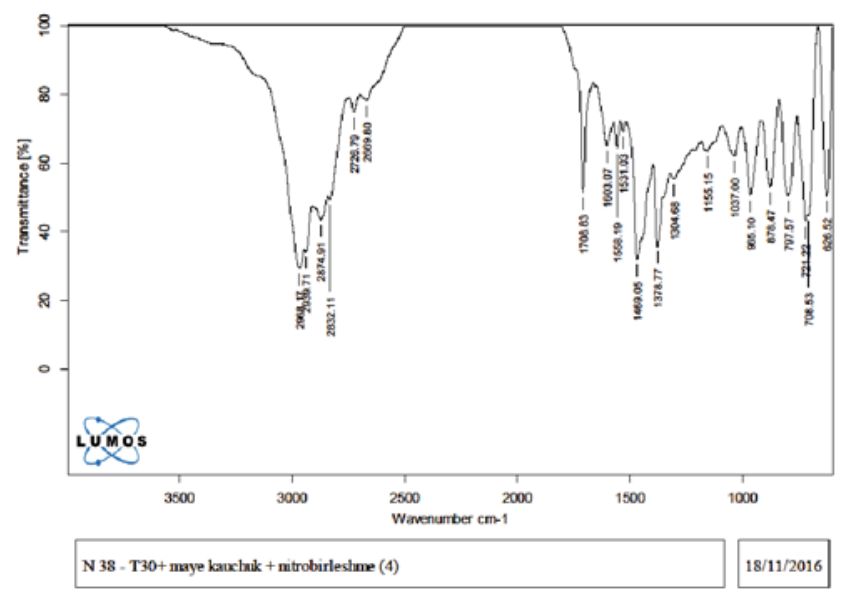

Figure 1.5. IR spectra of the $4^{\mathrm{mI}}$ point 


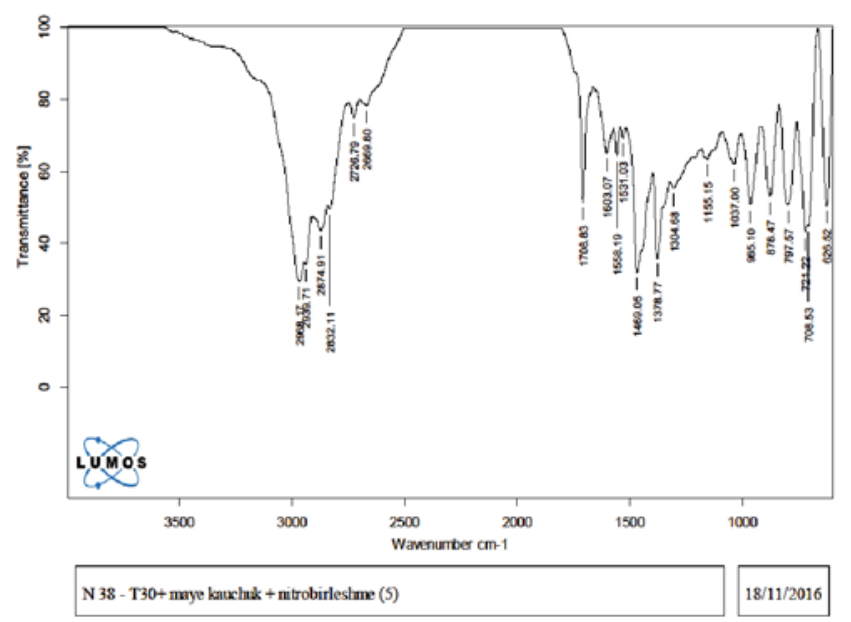

Figure 1.6. IR spectra of the $5^{\text {th }}$ point

proves that the conservation materials are distributed on the metal surface homogeneously.

STA-449 F3. NETZSCH thermal analyzer was used for the thermogravimetric analysis (TG/DTA - change in mass depending on the temperature and differential thermal analysis) of the prepared metalworking fluids (Fig. 2). The processes have been operated by using nitrogen gas flow and by increasing the temperature by $20^{\circ} \mathrm{C}$ per minute. The evaluation of thermal analysis of Sample 5 (Table 1) shows that there is no chemical change in the STA (Simultaneous Thermal Analysis) curve. the peak at $360^{\circ} \mathrm{C}$ coincides with the complete disintegration of the composition. The curve for the mass loss is observed in the TG (Thermogravimetry) curve which proves the homogeneity of the composition. The component that has less thermal stability in the studied MWF is nitro compound. Hence. nitro compounds are decomposed at temperatures above $600^{\circ} \mathrm{C}$. then the metal salts of the NPA and liquid rubber are decomposed respectively. The dependence of the change in the mass loss of the temperature is given in Table 2 .

Because of the uniform distribution of the components in the T-30 oil medium and thermostability property of the metal salts of the NPA. metalworking fluids can be utilized for a long time without losing quality.

Table 2. Change in the mass loss

\begin{tabular}{|c|c|c|}
\hline $\begin{array}{c}\text { Temperature } \\
{\left[{ }^{\circ} \mathrm{C}\right]}\end{array}$ & $\begin{array}{c}\text { Mass loss } \\
{[\mathrm{mg}]}\end{array}$ & $\begin{array}{c}\text { Mass loss } \\
{[\%]}\end{array}$ \\
\hline 120 & 0 & - \\
\hline 140 & 0.2 & 1.48 \\
\hline 160 & 0.4 & 2.96 \\
\hline 180 & 0.6 & 4.44 \\
\hline 200 & 1.0 & 7.41 \\
\hline 220 & 1.4 & 10.37 \\
\hline 240 & 2.6 & 19.25 \\
\hline 260 & 4.0 & 29.26 \\
\hline 280 & 6.0 & 44.44 \\
\hline 300 & 8.6 & 63.70 \\
\hline 320 & 11.0 & 81.48 \\
\hline 340 & 11.4 & 84.44 \\
\hline 360 & 11.4 & 84.44 \\
\hline 380 & 11.6 & 85.92 \\
\hline 400 & 11.8 & 87.64 \\
\hline 420 & 12.0 & 88.88 \\
\hline 440 & 12.0 & 88.88 \\
\hline 460 & 12.2 & 90.37 \\
\hline & &
\end{tabular}

The specific contact method has been used in order to determine the resistivity (specific conductance) of the compositions. The measurement process has been operated by the E6-13A teraohmmeter. The measurement places are cleaned with alcohol before each process and the distance between electrodes is determined. Then. the substance is poured until the area between electrodes is filled and the resistivity is measured. The resistivity is calculated according to $\mathrm{r}=\mathrm{pr}^{2} / \mathrm{d}$ equation and the conductance is determined with the following equation: $\sigma=1 / \mathrm{r}$. The physical components

Table 1. The main physical properties of the metalworking fluids

\begin{tabular}{|c|c|c|c|c|c|c|c|}
\hline \multirow[t]{2}{*}{ Name of the property } & \multirow{2}{*}{$\begin{array}{c}\text { Name of the } \\
\text { device }\end{array}$} & \multirow[t]{2}{*}{ ASTM } & \multicolumn{5}{|c|}{ Samples } \\
\hline & & & $\mathrm{I}$ & II & III & IV & $\mathrm{V}$ \\
\hline Freezing point ${ }^{\circ} \mathrm{C}$ & $\begin{array}{c}\text { Stanhope } \\
\text { Seta }\end{array}$ & $\begin{array}{l}\text { ASTM } \\
\text { D2386 }\end{array}$ & -35 & -30 & -25 & -25 & -25 \\
\hline Viscosity $\mathrm{mm}^{2} / \mathrm{s} .40^{\circ} \mathrm{C}$ & TW4000 & $\begin{array}{l}\text { ASTM } \\
\text { D445 }\end{array}$ & 60.88 & 56.47 & 61.96 & 66.93 & 53.99 \\
\hline Viscosity. $\mathrm{mm}^{2} / \mathrm{s} .100^{\circ} \mathrm{C}$ & TW4000 & $\begin{array}{l}\text { ASTM } \\
\text { D445 }\end{array}$ & 8.31 & 7.98 & 8.12 & 7.54 & 7.63 \\
\hline Density. $\mathrm{g} / \mathrm{cm}^{3}$ & DMA $4500 \mathrm{M}$ & D5002 & 0.9072 & 0.9112 & 0.9136 & 0.9093 & 0.9090 \\
\hline
\end{tabular}

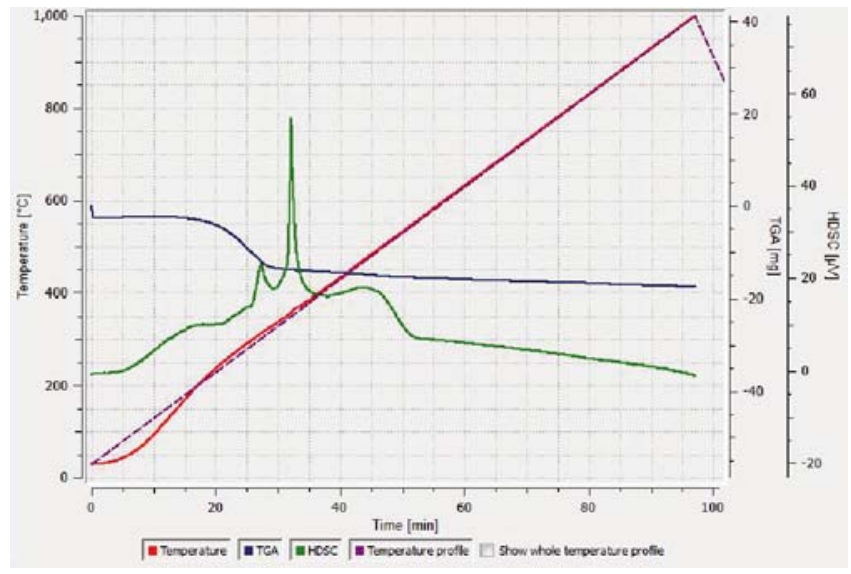

Figure 2. TG/DTA curves of the Sample 5 in the formulae are following: r-resistance. p-constant. $\sigma$-conductance. r-radius of the measurement electrode. d-distance between electrodes. The determined electrical conductivity values of the samples are shown in Table 3.

The graph (Fig. 3.) showing the change of the electrical conductivity of the metalworking fluids due to temperature is given below:

As can be seen from the tables (Table 3 and 4). there is a direct dependence between the electrical conductance and the corrosion protection effect of the metalworking fluids; the higher electrical conductance. the greater corrosion protection effect.

Obtained composition has been tested as MWF on steel plates by dissolving T-30 oil (5\%, 7\% and 10\%). 
Table 3. Change in the electrical conductivity due to temperature

\begin{tabular}{|c|c|c|c|c|c|c|c|c|c|}
\hline № & $\begin{array}{l}\text { Tempe- } \\
\text { rature. } \\
{[\mathrm{K}]}\end{array}$ & $\begin{array}{c}\text { Special } \\
\text { resistance } \\
\rho .[\text { Om } \cdot m]\end{array}$ & $\begin{array}{c}\text { Electrıcal } \\
\text { conductivit } \\
\text { y } \sigma .[S / s m]\end{array}$ & № & $\begin{array}{c}\text { Special } \\
\text { resistan. } \\
\rho .[\mathrm{Om} \cdot \mathrm{m}]\end{array}$ & $\begin{array}{c}\text { Electr. } \\
\text { cond. } \\
\sigma .[\mathrm{S} / \mathrm{sm}]\end{array}$ & № & $\begin{array}{c}\text { Special } \\
\text { resistan. } \\
\rho .[\mathrm{Om} \cdot \mathrm{m}]\end{array}$ & $\begin{array}{c}\text { Electr. } \\
\text { cond. } \\
\sigma .[S / s m]\end{array}$ \\
\hline \multirow[t]{13}{*}{1} & 298 & $6.9 \cdot 10^{8}$ & $1.4 \cdot 10^{-11}$ & \multirow[t]{13}{*}{2} & $8.4 \cdot 10^{8}$ & $1.1 \cdot 10^{-11}$ & \multirow[t]{13}{*}{3} & $1.08 \cdot 10^{10}$ & $9.2 \cdot 10^{-13}$ \\
\hline & 303 & $6 \cdot 10^{8}$ & $1.6 \cdot 10^{-11}$ & & $7.9 \cdot 10^{8}$ & $1.3 \cdot 10^{-11}$ & & $1.04 \cdot 10^{10}$ & $9.6 \cdot 10^{-13}$ \\
\hline & 308 & $6 \cdot 10^{8}$ & $1.6 \cdot 10^{-11}$ & & $7.4 \cdot 10^{8}$ & $1.4 \cdot 10^{-11}$ & & $1.04 \cdot 10^{10}$ & $9.6 \cdot 10^{-13}$ \\
\hline & 313 & $5.6 \cdot 10^{8}$ & $1.7 \cdot 10^{-11}$ & & $6.9 \cdot 10^{8}$ & $1.4 \cdot 10^{-11}$ & & $1 \cdot 10^{10}$ & $1 \cdot 10^{-12}$ \\
\hline & 318 & $5.6 \cdot 10^{8}$ & $1.7 \cdot 10^{-11}$ & & $6.5 \cdot 10^{8}$ & $1.5 \cdot 10^{-11}$ & & $9.2 \cdot 10^{9}$ & $1.1 \cdot 10^{-12}$ \\
\hline & 323 & $5.2 \cdot 10^{8}$ & $1.9 \cdot 10^{-11}$ & & $6.1 \cdot 10^{8}$ & $1.6 \cdot 10^{-11}$ & & $8 \cdot 10^{9}$ & $1.3 \cdot 10^{-12}$ \\
\hline & 328 & $5.2 \cdot 10^{8}$ & $1.9 \cdot 10^{-11}$ & & $5.9 \cdot 10^{8}$ & $1.7 \cdot 10^{-11}$ & & $6.8 \cdot 10^{9}$ & $1.5 \cdot 10^{-12}$ \\
\hline & 333 & $4.8 \cdot 10^{8}$ & $2.1 \cdot 10^{-11}$ & & $5.7 \cdot 10^{8}$ & $1.8 \cdot 10^{-11}$ & & $6 \cdot 10^{9}$ & $1.7 \cdot 10^{-12}$ \\
\hline & 338 & $4.6 \cdot 10^{8}$ & $2.2 \cdot 10^{-11}$ & & $5.3 \cdot 10^{8}$ & $1.9 \cdot 10^{-11}$ & & $5 \cdot 10^{9}$ & $2 \cdot 10^{-12}$ \\
\hline & 343 & $4.2 \cdot 10^{8}$ & $2.4 \cdot 10^{-11}$ & & $4.9 \cdot 10^{8}$ & $2 \cdot 10^{-11}$ & & $4 \cdot 10^{9}$ & $2.5 \cdot 10^{-12}$ \\
\hline & 348 & $3.8 \cdot 10^{8}$ & $2.6 \cdot 10^{-11}$ & & $4.6 \cdot 10^{8}$ & $2.2 \cdot 10^{-11}$ & & $3.6 \cdot 10^{9}$ & $2.8 \cdot 10^{-12}$ \\
\hline & 353 & $3.8 \cdot 10^{8}$ & $2.6 \cdot 10^{-11}$ & & $4.1 \cdot 10^{8}$ & $2.4 \cdot 10^{-11}$ & & $3.2 \cdot 10^{9}$ & $3.1 \cdot 10^{-12}$ \\
\hline & 358 & $3.2 \cdot 10^{8}$ & $3.1 \cdot 10^{-11}$ & & $3.8 \cdot 10^{8}$ & $2.6 \cdot 10^{-11}$ & & $2.8 \cdot 10^{9}$ & $1.3 \cdot 10^{-12}$ \\
\hline
\end{tabular}

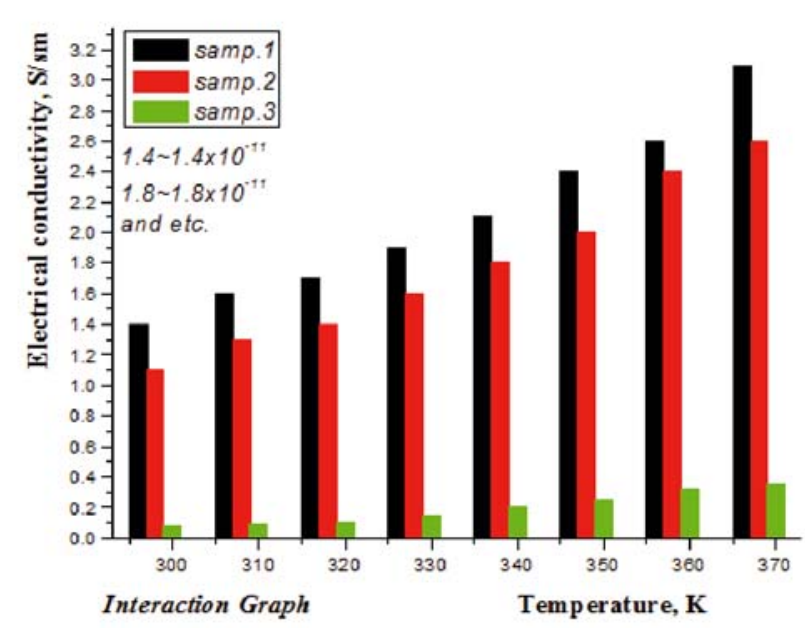

Figure 3. The graph of electrical conductivity against temperature

The experiments were carried out with DC01 (CR4) carbon steel specimens. The mainly chemical composition (wt \%) of the carbon steel was listed as follows: $\mathrm{C} \% \sim 0.07$; $\mathrm{Si} \% \sim 0.01 ; \mathrm{Mn} \% \sim 0.2-0.35 ; \mathrm{Ni} \% \sim 0.06 ; \mathrm{S} \% \sim 0.025$; $\mathrm{P} \% \sim 0.02 ; \mathrm{Cr} \% \sim 0.03 ; \mathrm{Al} \% \sim 0.02-0.07 ; \mathrm{Cu} \% \sim 0.06 ; \mathrm{Fe}$ balance. The test sample size was $150 \times 100 \times 1 \mathrm{~mm}$. The carbon steel plates were prepared. degreased and cleaned with deionized water and alcohol.

The experiment has been operated according to the current standards in the chamber called «CORROSIONBOX-1000E» which is considered as a modern technological device. The process has been carried out in two phases: condensation and atmospheric phase. Electronic appliances have been used in order to adjust the standard parameters for obtaining sustainable trials in the experiment chamber. For the condensation phase. these parameters are the temperature of the chamber and the duration of the trial. for the environmental phase. these are the temperature of the moisturizing agent and the chamber and the duration of the trial. The duration of the trial was in the interval of 1 minute - 9999 hours and the temperature of the chamber was $20-50^{\circ} \mathrm{C}$ for the condensation phase. whereas the temperature of the moisturizing agent was $20-80^{\circ} \mathrm{C}$ and the remaining parameters were the same for the environmental phase.

\section{RESULTS AND DISCUSSION}

As can be clearly seen from the table. metal sheets were protected 31 and 56 days by using T-30 turbine oil and liquid rubber respectively. however. these pointers were higher when the inhibitor was used. When $7 \%$ concentration of the inhibitor (Co salt of NPA + nitro compound + liquid rubber) was used. in the condensation phase. the protection of the metal sheets from the corrosion lasted 301 days. however. in environmental phase. it was 384 days. In $10 \%$ concentra-tion. it was 322 and 401 days. respectively. At the same time. the corrosion protection efficiency of the conservative liquids those have been produced on the basis of the complex of the metal salts ( $\mathrm{Ni}, \mathrm{Zn}, \mathrm{Mg}$ and $\mathrm{Ba}$ ) of NPA with nitro compounds was high in comparison to current demand.

The dependence graph (Fig 4.) of the trial results of composition type metalworking fluids on the concentration of the inhibitor is shown below:

As it is clear from the Figure 4. the highest result was obtained from the metalworking fluid which is synthesized by the composition of Co salt of the NPA (curve B).

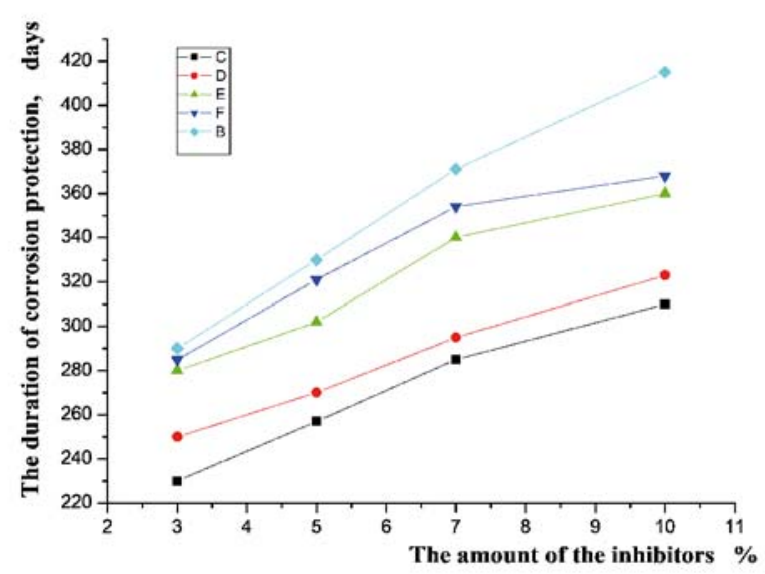

B - T-30 oil + Liquid rubber + Co salt of the NPA+ Nitro compound $\mathrm{F}-\mathrm{T}-30$ oil + Liquid rubber $+\mathrm{Ni}$ salt of the NPA+ Nitro compound $\mathrm{E}-\mathrm{T}-30$ oil + Liquid rubber $+\mathrm{Zn}$ salt of the NPA+ Nitro compound $\mathrm{D}-\mathrm{T}-30$ oil + Liquid rubber + Mg salt of the NPA+ Nitro compound C - T-30 oil + Liquid rubber + Ba salt of the NPA+ Nitro compound

Figure 4. The graphical illustration of the trial results of the metal salts of NPA as composition type metalworking fluids 
Table 4. The results of the trials of synthesized salts as metalworking fluids both individually and as compositions

\begin{tabular}{|c|c|c|c|c|c|}
\hline \multirow{3}{*}{ № } & \multicolumn{3}{|c|}{ The solutions of the compositions in the "T- 30 " oil } & \multicolumn{2}{|c|}{ The duration of corrosion protection. [days] } \\
\hline & \multirow{2}{*}{ Content } & \multicolumn{2}{|c|}{ The amount of the components [\%] } & \multirow[t]{2}{*}{ condensation phase } & \multirow[t]{2}{*}{ atmospheric phase } \\
\hline & & inhibitor & solution & & \\
\hline 1. & T-30 oil + Liquid rubber & - & - & 31 & 56 \\
\hline 2. & $\begin{array}{l}\text { Co salt of the NPA } \\
\text { Liquid rubber }\end{array}$ & $\begin{array}{l}5 \\
5\end{array}$ & 10 & 138 & 219 \\
\hline 3. & $\begin{array}{l}\text { Co salt of the NPA } \\
\text { Nitro compound } \\
\text { Liquid rubber }\end{array}$ & $\begin{array}{l}1.66 \\
1.66 \\
1.66\end{array}$ & 5 & 228 & 317 \\
\hline 4. & $\begin{array}{l}\text { Co salt of the NPA } \\
\text { Nitro compound } \\
\text { Liquid rubber }\end{array}$ & $\begin{array}{l}2.33 \\
2.33 \\
2.34\end{array}$ & 7 & 301 & 384 \\
\hline 5. & $\begin{array}{l}\text { Co salt of the NPA } \\
\text { Nitro compound } \\
\text { Liquid rubber }\end{array}$ & $\begin{array}{l}3.33 \\
3.33 \\
3.34 \\
\end{array}$ & 10 & 322 & 401 \\
\hline 6. & $\begin{array}{l}\text { Ni salt of the NPA } \\
\text { Liquid rubber }\end{array}$ & $\begin{array}{l}5 \\
5\end{array}$ & 10 & 95 & 197 \\
\hline 7. & $\begin{array}{l}\text { Ni salt of the NPA } \\
\text { Nitro compound } \\
\text { Liquid rubber }\end{array}$ & $\begin{array}{l}2.33 \\
2.33 \\
2.34 \\
\end{array}$ & 7 & 267 & 311 \\
\hline 8. & $\begin{array}{l}\text { Ni salt of the NPA } \\
\text { Nitro compound } \\
\text { Liquid rubber }\end{array}$ & $\begin{array}{l}3.33 \\
3.33 \\
3.34\end{array}$ & 10 & 291 & 350 \\
\hline 9. & $\begin{array}{l}\text { Zn salt of the NPA } \\
\text { Nitro compound } \\
\text { Liquid rubber }\end{array}$ & $\begin{array}{l}3.3 .3 \\
3.3 .3 \\
3.3 .4\end{array}$ & 10 & 263 & 326 \\
\hline 10. & $\begin{array}{l}\text { Mg salt of the NPA } \\
\text { Nitro compound } \\
\text { Liquid rubber }\end{array}$ & $\begin{array}{l}3.33 \\
3.33 \\
3.34\end{array}$ & 10 & 297 & 353 \\
\hline 11. & $\begin{array}{l}\text { Ba salt of the NPA } \\
\text { Nitro compound } \\
\text { Liquid rubber }\end{array}$ & $\begin{array}{l}3.33 \\
3.33 \\
3.34\end{array}$ & 10 & 289 & 346 \\
\hline
\end{tabular}

The long lasting influence of the aggressive environment on the metallic surface degrades the protective layer. as a consequence. the coating loses its function at the certain level of the experience.

As it is obvious from the Table 5. the lubricant which is produced when $10 \%$ of technical paraffin ${ }^{27}$ is added to the MWF (Sample-I) which has the highest efficiency in "corrosionbox" protects metal plates for 356 and 423 days in condensation and environmental phase. respectively. At the same time. the lubricants which are prepared by other metalworking fluids show high anti - corrosion effect during the trial.

\section{Scanning Electron Microscopy Analysis (SEM)}

Scanning Electron Microscope (SEM: S-3400N HITACHI ) morphologies the steel plates in the corrosion box in the absence and presence of MWF were shown in Figure 5.1-5.4 respectively. Figure 5.1 shows the clean surface of steel sample before immersing in MWF. This figure reveals the homogeneity of the surface. Figure 5.2 shows the general appearance of mild steel without inhibitor (only T-30 oil). It can be seen from the figure that the surface of steel plates was extremely damaged in the absence of the inhibitor. Figure 5.3 and 5.4 reflect the SEM morphology of the steel specimen at lower concentration (5\%) and higher concentration (10\%) of the MWF. From the figures it is clear that at low concentration (5\%) of the MWF only few constituents cover the surface which are not enough to afford a protective layer and hence dissolution of mild steel is observed to some extent whereas at higher concentration (10\%) the constituents present are large enough to form a protective layer regarding the dissolution of steel plates.

As a result of the experiments. it has been revealed that. the inhibitor properties of the compositions of mineral oils with these kinds of mixture of complexes are more effective than the individual compositions with the same concentration those are prepared by adding salt and nitro compounds to the mineral oils separately. It can be explained by the superior ability of chemisorption on the metal surface and producing stronger coating for protection from corrosion of these complexes. On the other hand. these compounds are stronger ligands than the water that is why they can substitute water molecules from the surface of the metal and create strong protection layer.

\section{CONCLUSION}

As can be seen from the table which indicates the results of the experiments. the manufactured MWF may be used in order to protect the metals from corrosion

Table 5. The trial results of the lubricants

\begin{tabular}{|c|c|c|c|c|}
\hline \multirow[t]{2}{*}{ № } & \multirow{2}{*}{ MWF $90 \%$ + paraffin $10 \%$} & \multirow{2}{*}{ The total amount of the inhibitor in the sample [\%] } & \multicolumn{2}{|c|}{ The duration of corrosion protection. [days] } \\
\hline & & & condensation phase & environmental phase \\
\hline 1 & I + paraffin & 10 & 356 & 423 \\
\hline 2 & II + paraffin & 10 & 341 & 403 \\
\hline 4 & IV + paraffin & 10 & 332 & 378 \\
\hline 5 & $V+$ paraffin & 10 & 304 & 352 \\
\hline
\end{tabular}




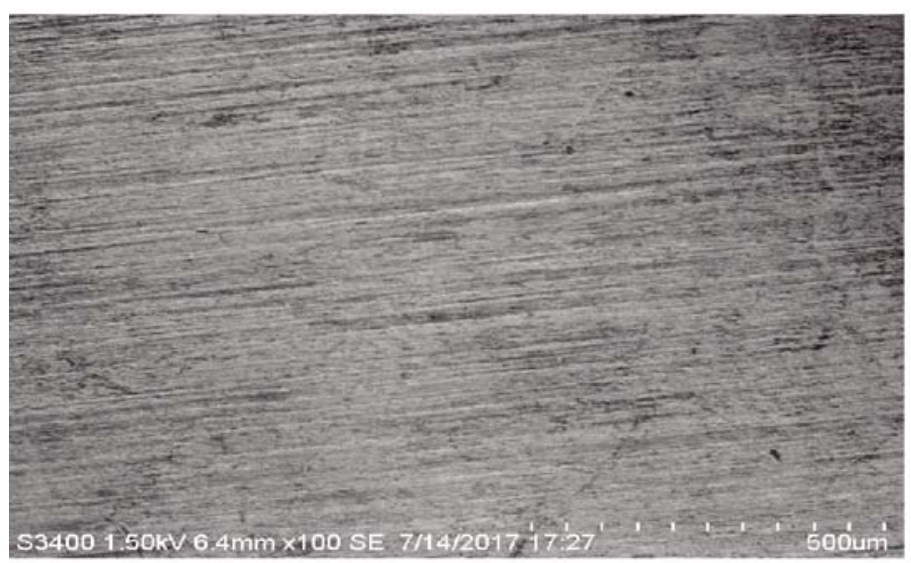

Fig. 5.1 before the immersion test.

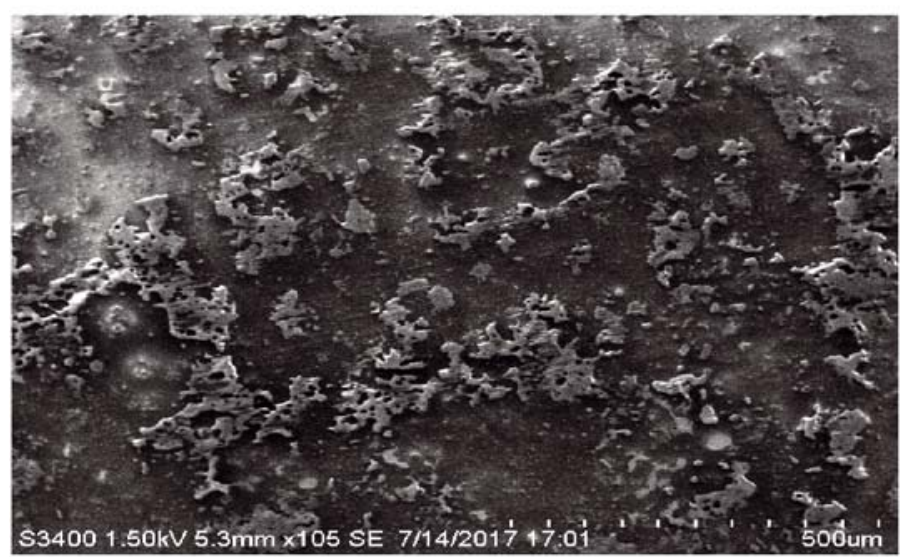

Fig. 5.3 after the immersion test (at $5 \%$ concent.)

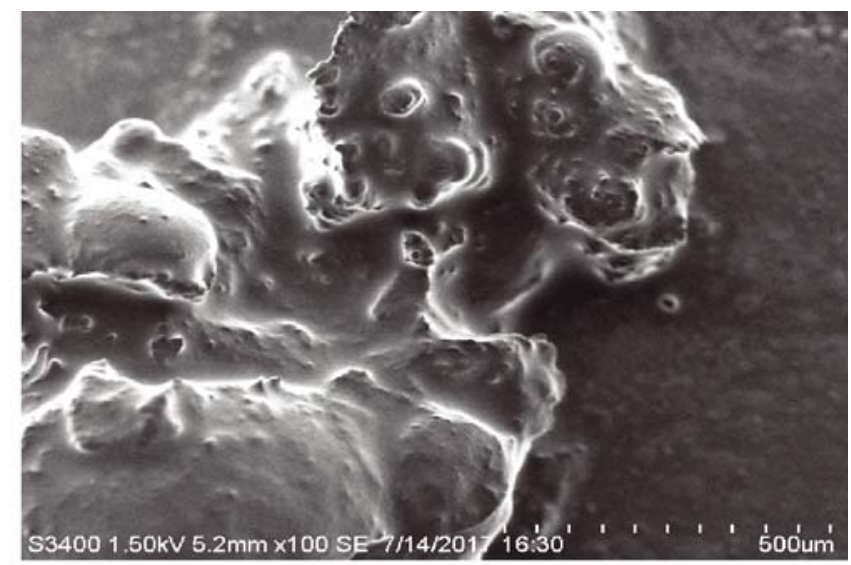

Fig. 5.2 after the immersion test (without inhi-bitor)

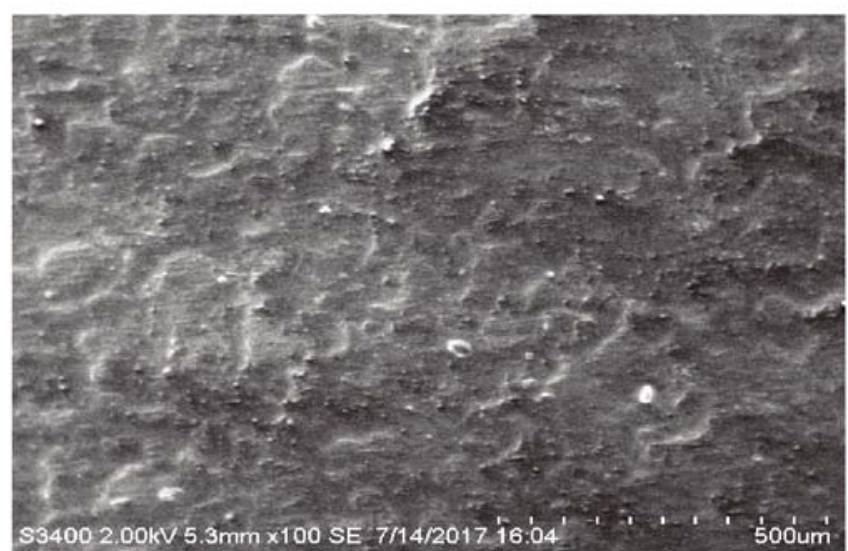

Fig. 5.4 after the immersion test (at $10 \%$ concent.)

Figure 5.1-5.4. SEM Images of MWF specimens; before and after the immersion test

for industrial purposes. The components those have been used for producing MWF are cost effective and environmentally - friendly. on the other hand. they have simple manufacturing technology and rich feedstock. T-30 oil. additives which are used as inhibitors and liquid rubber which are used in the reaction medium are produced on the basis of the feedstock which has enough reserves. So. the comparative analysis of the results reveals that the usage of the compositions of the metal salts of natural petroleum acids with nitro compounds as inhibitors have a practical importance for producing more effective MWF.

It has been revealed that the metalworking fluids that are produced by the composition of the synthesized inhibitor and nitro compound in the presence of liquid rubber has a great protection against corrosion than their individual usages. meets the requirements and has a great practical importance.

\section{ACKNOWLEDGMENT}

The authors are grateful for financial support of Research Institute of Petrochemical Processes named after Academician Yu.G.Mamedaliyev. Baku. Azerbaijan.

\section{LITERATURE CITED}

1. Rozenfeld, I.L. 1981. Corrosion Inhibitors; McGraw-Hill. New York. p. 182.

2. Roberge, P.R. 2008. Corrosion Engineering Principle and Practice. McGraw-Hill. New York. 730 p.
3. McCoy, J.S. (2006). Introduction: Tracing the Historical Development of Metalworking Fluids, in Metalworking Fluids; Byers. J.P. Ed.; 2nd edition. Taylor \& Francis. New York. pp. 1-18.

4. Brinksmeier, E., Meyer, D., Huesmann-Cordes, A.G. \& Herrmann, C. (2015). Metalwor-king fluids-Mechanisms and performance. CIRP Ann. Manufact. Technol. 64, 605-628 (http://creativecommons.org/ licenses/by-nc-nd/4.0/).

5. Hugh Spikes (2008). Low- and zero-sulphated ash. phosphorus and Sulphur anti-wear additives for engine oils. Lubrication Sci. 20,103-136 DOI: 10.1002/1s.57.

6. Fouda, A.S., Elmorsi, M.A. \& Abou-Elmagd, B.S. (2017). Adsorption and inhibitive properties of methanol extract of Eeuphorbia Heterophylla for the corrosion of copper in 0.5 M nitric acid solutions. Pol. J. Chem. Technol. 19(1), 95-103. DOI: $10.1515 /$ pjct-2017-0014.

7. Dharma, R., Kodali. (2002). "High performance ester lubricants from natural oils". Ind. Lubr. Tribol. 54(4) 165-170. http://dx.doi.org/10.1108/00368790210431718

8. Zvirko, O.I., Mytsyk, A.B., Tsyrulnyk, O.T., Gabetta, G. \& Nykyforchyn, H.M. (2017). Corrosion Degradation of Steel of an Elbow of Gas Pipeline with Large-Scale Delamination after Long-Term Operation. Mater. Sci. 52(6). 861-865 https:// doi.org/10.1007/s11003-017-0032-8.

9. Ghai, I., Wentz, J., DeVor, R.E., Kapoor, S.G. \& Samuel, J. (2010). Droplet behavior on a rotating surface for atomization-based cutting fluid application in micromachining. J. Manuf. Sci. Eng. 132(1). 011017 DOI:10.1115/1.4000859

10. Myshkin, N.K. \& Markova, L.V. (2016). Methods and Instruments for Condition Monitoring of Lubricants. In: On-line Condition Monitoring in Industrial Lubrication and Tribology. Appl. Condit. Monitoring, 8, 1-29 Springer. Cham. https://doi. org/10.1007/978-3-319-61134-1_1 
11. Zhao, F., Urbance, M. \& Skerlos, S.J. (2004). Mechanistic Model of Coaxial Microfiltration for Semi-Synthetic Metalworking Fluid Microemulsions. J. Manufact. Sci. Enginee. 126(3), 435. http://doi.org/10.1115/1.1763187.

12. Shujun, Gao, Peng, Jin, Bruce, Brown and etc. (2017). Corrosion behavior of mild steel in sour environments at elevated temperatures. Corrosion. Vol. 73. No. 8. pp. 915-926 https:// doi.org/10.5006/2366

13. Aiad, I., Riya, M.A., Tawfik, S.M. \& Abousehly, A.M. (2016). Protection of carbon steel against corrosion in hydrochloric acid solution by some synthesized cationic surfactants. 52: 339. https://doi.org/10.1134/S2070205116020027

14. Skerlos, S.J., Rajagopalan, N., DeVor, R.E., Kapoor, S.G. \& Angspatt, V.D. (2001). Microfiltration of Polyoxyalkylene Metalworking Fluid Lubricant Additives Using Aluminum Oxide Membranes. J. Manufact. Sci. Enginee. 123(4), 692. http://doi. org/10.1115/1.1392993.

15. Thomas Norrby. (2003). Environmentally adapted lubricants - where are the opportu-nites? Ind. Lubr. Tribol. 5(6), 268-274. https://doi.org/10.1108/00368790310496400.

16. Skerlos, S.J. (2011). Cutting Fluids and their Environmental Impact. Chap. Encyclop. Tribol. Springer. http://doi. org/10.1007/978-0-387-92897-5.

17. MacLean, D., Hayes, K., Barnard, T., Hull, T., Park, Y.E. \& Skerlos, S.J. (2009). Impact of Supercritical Carbon Dioxide Metalworking Fluids on Tool Life in turning of Sintered Steel and Milling of Compacted Graphite Iron. Proceed. ASME Inter. Manufact. Sci. Enginee. Conference 2009. MSEC2009, October 4-7, 2009. West Lafayette. Indiana. USA. pp. 43-48.

18. Singh, B.P., Nayak., S., Nanda. K., Bikash, K.J., Bhattacharjee, S. \& Besra, L. (2013). The production of a corrosion resistant graphene reinforced composite coating on copper by electrophoretic deposition. Carbon 61, 47-56. DOI: 10.1016/j. carbon.2013.04.063.

19. Kaiyue, Li., Guoding Chen, Deng Liu. (2016). Study of the influence of lubrication parameters on gear lubrication properties and efficiency. Ind. Lubr. Tribol. 68(6). 647-657. https:// doi.org/10.1108/ILT-06-2015-0089

20. Chang, S.C., Rihana, A., Bahrman, S., Gruden, C.L., Khijniak, A.I., Skerlos, S.J. \& Adriaens, P. (2004). Flow cytometric detection and quantification of mycobacteria in metalworking fluids. Inter. Biodeterioration \& Biodegradation 54(2-3), 105-112. http://doi.org/10.1016/j.ibiod.2004.03.019

21. Hernández Gayosso, M.J. Nava, N. \& Zavala, G. Olivares. (2016). Characterisation and comparison of corrosion products originated in steel pipelines transporting sour gas and crude oil. Inter. J. Corr. Process. Corr. Control 51(8), 626-634. http://dx.doi.org/10.1080/1478422X.2016.1173421.

22. Bhanudas Dattatraya Bachchhav, Geeta, S. Lathkar. Harijan Bagchi. (2014). Tribology of drawing lubricants for low carbon steel. Ind. Lubr. Tribol. 66(6), 640-644. https://doi. org/10.1108/ILT-10-2012-0105.

23. Nasirov, F.A. (1983). Issledovaniye i razrabotca prochessa polucheniya nizcomolekulyar-noqo polibutadiyena $\mathrm{v}$ prisutstvii cataliticheskix sistem na osnove orqanichescix ditioproizvodnix nicelya (cobalta). Diss... cand.xim.nauk.. Baku. IPP ANAS 202 p.

24. ASTM C 613-14: 'Standard test method for constituent content of composite prepreg by Soxhlet Extraction'.

25. van de Voort, F.R., Sedman, J. \& Pinchuk, D. (2011). An overview of progress and new developments in FTIR lubricant condition monitoring methodology. J. ASTM Int. 8(5). ID: JAI103344Google Scholar.

26. Zimmerman, J.B., Hayes, K.F. \& Skerlos, S.J. (2004). Influence of Ion Accumulation on the Emulsion Stability and Performance of Semi-Synthetic Metalworking Fluids. Enviromen. Sci. Technol, 38(8), 2482-2490. http://doi.org/10.1021/ es0340477

27. Li Ming Chu, Jaw-Ren Lin, Yuh-Ping Chang. \& ChungChun Wu. (2016). Elastohydrodynamic lubrication of circular contacts at pure squeeze motion with micropolar lubricants. Ind.
Lubr. Tribol. 68(6) pp. 640-646. https://doi.org/10.1108/ILT10-2015-0139. 